
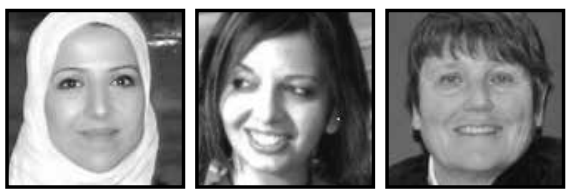

\title{
Autobiographical Narrative Inquiry: Tellings and Retellings
}

\author{
Muna Saleh, Jinny Menon, and D. Jean Clandinin \\ University of Alberta
}

\begin{abstract}
Questions of diversity and inclusion are central to learning to engage in narrative inquiry. By engaging in autobiographical narrative inquiry (Clandinin \& Caine, 2012; Clandinin \& Connelly, 2000), we tell and retell stories related to diversity. In doing so, we puzzle about inquiring in ethical ways alongside diverse participants. We tell and retell three stories in our efforts to break with the taken-for-granted in our lives. We draw forward resonances around the challenging, yet ethical necessity, of facing ourselves (Anzaldua, 1987/1999; Lindemann Nelson, 1995) as we attend to the complexity of lives.
\end{abstract}

\section{Introduction}

This is, in part, an effort to gain perspective on our constructs and our categories, to break through what Dewey once called "the crust of conventionalized and routine consciousness." My reasons for wanting to make this effort have to do with a desire to communicate a sense of how haunted I often feel, how badly I want to break with the taken-for-granted, to see and to say .... My interest in coping with diversity and striving toward significant inclusion derives to a large degree from an awareness of the savagery, the brutal marginalizations, the structured silences, the imposed invisibility so present all around. (Greene, 1993, p. 211)

e revisited Maxine Greene's (1993) words in the midst of discussing potentialities for this article. They compelled us to sit in silence for several moments as we felt the reverberations in our bodies and the spaces 
between us. Greene calls us to fully attend to diversity in our research relationships, to "break with the taken-for-granted, to see and to say" as inquirers. We wondered about researcher-participant relationships, relationships where participants can be expected to conform to the researcher's expectations. We wondered how to break with the taken-for-granted, how to make visible the unintended instances of "savagery, the brutal marginalizations, the structured silences, the imposed invisibility" as we inquire alongside research participants. Understanding diversity as the profound acknowledgement "that there cannot be a single standard of humanness or attainment or propriety when it comes to taking a perspective on the world" (Greene, 1993, p. 212), we puzzled about how we could ethically come alongside diverse participants in classrooms, schools, homes, community places, and in all the varied landscapes where lives and relationships are being composed.

\section{Methodology}

As narrative inquirers, we hold relationships central to the living out of our inquiries (Clandinin \& Connelly, 2000; Huber, Clandinin, \& Huber, 2006). Our puzzle in this article is shaped by this embodied relationality expressed in narrative inquiry:

People shape their daily lives by stories of who they and others are and as they interpret their past in terms of these stories. Story, in the current idiom, is a portal through which their experience of the world enters the world and by which their experience of the world is interpreted and made personally meaningful. Viewed this way, narrative is the phenomenon studied in inquiry. Narrative inquiry, the study of experience as story, then, is first and foremost a way of thinking about experience. Narrative inquiry as a methodology entails a view of the phenomenon. To use narrative inquiry methodology is to adopt a particular narrative view of experience as phenomena under study. (Connelly \& Clandinin, 2006, p. 477)

We bring stories of who we are and are becoming as teachers, students, parents, researchers, all of our "selves ... always in the making" (Greene, 1993, p. 213), with us into our inquiries. In this way, we understand that narrative inquiry is necessarily autobiographical: "Because narrative inquiry is an ongoing reflexive and reflective methodology, narrative inquirers need to continually inquire into their experiences before, during, and after each inquiry" (Clandinin \& Caine, 2012, p. 171). Through the following autobiographical tellings and retellings into who we are and who we are becoming as narrative inquirers, we work to break with the taken-for-granted by 
positioning ourselves within the metaphorical three-dimensional narrative inquiry space with dimensions of temporality, sociality, and place (Clandinin \& Connelly, 2000). ${ }^{1}$ In exploring who we are and who we are becoming, in viewing ourselves and our participants as always in the midst of stories, we embody our ontological and ethical commitments to live and inquire alongside one another, relationally (Clandinin \& Caine, 2012).

\section{Telling Muna's Story}

"For such a thin piece of fabric .... the hijab can be pretty weighty." Even as I spoke the words, I was aware of their disruption to so many of my lived stories. I was not surprised by the words themselves, for they were intentionally spoken. Rather, I was surprised at the very intentionality of their utterance. Where was my usual and purposeful silence of anything hijab-related ... especially on school landscapes? Looking around the Research Issues table, ${ }^{2}$ a space I had become familiar with over the past year and a half, I continued speaking and discussed the weight of others' gaze and expectations-a weightiness I can feel-of what my hijabi-world should be, or is probably, like. As I spoke, the looks, nods, and murmurs of recognition narrated for me the sense of the rightness of their utterance. They narrated the sense that self or other-imposed silence does not dwell in this space.

\section{Retelling Muna's Story}

As a Muslim woman who wears a hijab (headscarf), this story gives a sense of a moment of profound disruption to one of my stories to live by ${ }^{3}$ (Connelly \& Clandinin, 1999) on a school landscape. I experienced an embodied sense of tension as I travelled back along the temporal continuum and recalled in-school and out-of-school places in landscapes of days gone by where I felt safety in silence. However, this sense of safety within silence is double-edged because, similar to Greene, I have often been drawn by a strong "desire to communicate a sense of how haunted I often feel ... to see and to say" (p. 211). I was further dispositioned as I inquired within the liminal spaces (Heilbrun, 1999) of this story to live by, experiencing a heady sense of unsteadiness, for I recognized that my silence has often been self-imposed, serving as a defensive wall to deflect harmful words, looks, and energy.

Vivian Paley (1995) reminds me that community-building necessarily involves finding ways to "explain who we are" (p. 57), and who we are becoming, to one another. As I turned to inquire into this expression of my stories to live by, as I inquired into who I am and who I am becoming in relation to and with others, I engaged in self-facing 
(Anzaldua, 1987/1999; Lindemann Nelson, 1995). I wondered what stories I had silenced, and what silences I had created, for others in my chosen community ${ }^{4}$ (Lindemann Nelson, 1995) at the Research Issues table. In this moment of self-facing, I awakened to the ways in which my self-constructed barrier has, inevitably, prevented relational understandings woven within reciprocity and vulnerability, woven within one of my chosen communities.

I live in, shape, and have been shaped by, personal, cultural, familial, linguistic, social, and institutional narratives (Clandinin, 2013). While deeply personal, my decision to wear the hijab is also extremely visible and public, carrying with it a myriad of stories-stories that shift depending upon the eye of the beholder. Some of these stories hearten and sustain me; some confuse and irritate me; and some intimidate and frighten me. Although the stories shift depending upon the beholder, I often feel the weight of each beholder's single story (Adichie, 2009) of who/what I am and who/what I should be like in their stories of a woman who wears a hijab. I often feel their stories of me bumping up ${ }^{5}$ against my stories to live by, stories that are multiple, multifaceted, experiential, contextual, and always shifting. Feeling this weightiness and the bumping up of, at times, conflicting stories (Connelly \& Clandinin, 1999) caused me, over time, to construct a defensive wall of silence. I became accustomed to sharing the more intimate facets of my identity very carefully — with certain people, at certain times, and in certain places. This very much depends upon whether I feel safe.

Revisiting that Tuesday afternoon at the Research Issues table, I remember how feeling safe lowered my defensive wall enough to allow me to break the silence and tell my feelings related to the hijab for the first time ever on a school landscape. My sense of safety at that table space was developed and nurtured with time and in this chosen community. Engaged in self-facing during this extremely uncharacteristic moment of speaking, I am increasingly aware of the ways my self-imposed silence could profoundly shape my research relationships, and how they could be marked by unintentional "structured silences" (Greene, 1993). As I think about how to ethically live and inquire alongside diverse participants, how to honour our multiple stories to live by, Clandinin and Caine (2012) remind me that "it is important to understand narrative inquiry spaces as spaces of belonging for both researchers and participants; spaces that are always marked by ethics and attitudes of openness, mutual vulnerability, reciprocity, and care" (p. 169). My eyes linger on the words "mutual vulnerability" and I sense that I will continue to struggle against the urge to hide behind silence as I work to co-compose spaces of belonging alongside diverse participants. Looking forward to a multiperspectival narrative inquiry (see, for example, Chung, 2008; Houle, 2012; Huber, Murphy, \& Clandinin, 2011) alongside Muslim children, their families, and teachers, I am 
aware of the ethical necessity of struggling against silence, for how can I be fully present in a caring, open, and reciprocal relationship if vulnerability is a one-sided expectation?

\section{Telling Jean's Story}

I greeted Sean Lessard, a co-researcher on the Early School Leavers project, at my office door. Beside him stood a young man of Asian heritage dressed in jeans and a T-shirt that showed off his tattooed arms. I made eye contact with him as Sean introduced him as someone who might be interested in participating in the research. "Hello Truong," I said. I maintained eye contact, careful not to look at the multiple tattoos, knowing the tattoos were intentional markers on his skin and also knowing my questions or surprise in his appearance could shift the conversation away from his interest in engaging in the study. I was aware that I was an older white woman who worked in a university, while he was someone who had left school prior to graduating. Had I focussed on the differences that seemed so profound, the possibility of conversations would vanish. As we stood there in the office doorway, we gazed at each other and wondered-at least I did-about the ways a relationship might be composed. He agreed to participate.

\section{Retelling Jean's Story}

As I turn to retell this storied experience through narrative inquiry, I think about that moment of meeting, that moment when Truong stood in the doorway of my university office. I was nervous for the days and hours after I learned that Sean was bringing Truong to my office to meet me, for Truong to decide if he wanted to participate in our study. We needed participants and Sean was sure that we would learn from Truong.

I knew so little about Truong from Sean and had formed no images of him in my mind, except that he had left school before graduating. My earlier stories of who left school before graduating had already begun to crack open as the research team met many youth who challenged our too-easy, too-defined category of early school leavers, those we had initially termed school drop-outs. But in my experience in the doorway other images swirled in my mind. My experiences of growing up in a small rural farming community in the 1950s and 1960s did not include tattooed bodies. Skin markings were always the ones marked on bodies by birth or by accidents. No one intentionally engraved their bodies. I had, of course, since then, confronted many stereotypes of those who engraved their skins, but some of those were fostered in crime novels and sensational journalism. Those images also swirled in my mind. I knew though that it was important not to let those images formed in childhood and in reading be the dominant images expressed in the moment of meeting Truong. I knew he would already have 
been judged and categorized many times by older people who saw him only as the bearer of tattoos - not as someone who was living a deeply complex life, which included leaving school early.

I felt nervous at the moment of meeting Truong, in part, because of who I was as an older, white well-educated woman but also because I knew that Truong would teach us something if he would talk with us. In that moment of meeting and making sense of who I was in relation with Truong, I confronted myself in a moment of self-facing (Anzaldua, 1987/1999; Lindemann Nelson, 1995), seeing me as perhaps Truong saw me and knowing how I, too, was becoming, changing, reaching past and over categories to try to see Truong as a person with experiences. I was trying, as Adichie (2009) reminded me, not to see him as a single story, nor to see myself as a single story, but to see myself as if in the midst and to also see him as in the midst. I had intentions, a forward-looking story of desiring Truong to be part of the research. Truong, too, must have been in the midst of composing a forward-looking story. However, perhaps his forward-looking story was composed around loyalty to his much-loved teacher, Sean. But he agreed to meet me and consider being part of the study. It was a space with many possibilities in that moment as we negotiated who we were and who we might become in relation. As we gazed at each other, more unsaid than said, I was wondering if we could co-create a belonging space between us, a space marked by "attitudes of openness, vulnerability, reciprocity, and care" (Clandinin \& Caine, 2012, p. 167).

\section{Telling Jinny's Story}

The girl I knew in my Grade 6 classroom was bright, articulate, and possessed a mischievous sense of humour. Within what I perceived was a safe space, I believed she felt comfortable enough to enact a plotline which cast her as a strong female student. Unlike some of the other students in my class, she had no difficulty asserting her opinion when it differed from her peers. She was a natural leader, often taking charge during science class when students worked in cooperative groups, vying for lead roles in the dramatic plays we put on, and even volunteering first to read aloud whenever the occasion arose. However, not too far into the school year, her father informed me of his intentions to remove his daughter from my class and send her to a boarding school in India. His reasoning had been that she wasn't learning what she needed to learn here in Canada. He wished for an obedient daughter, one who would not talk back. I understood moving to a new school away from her homeland, her family and friends would alter the spaces my student had found herself in, and I wondered how her lived and imagined selves would be shaped by the different landscapes she would now occupy. 


\section{Retelling Jinny's Story}

As an elementary school teacher I was living out a Canadian school story of equality and safety. Within this story, my students were not merely encouraged but also expected to be treated equally, irrespective of gender. The dominant story of school (Clandinin \& Connelly, 1995) was that within the school, teachers were supposed to create safe spaces for all of their students. I held onto this story of school little realizing the danger I was courting in not being attentive to the possibility of other stories (Adichie, 2009) being lived out by those around me. As an Indo-Canadian teacher in a school with a predominately Indo-Canadian student population, I was fully vested in this particular dominant story of school. This insider's perspective I believed I held, one which I took for granted (Greene, 1993), should have inoculated me against the nuanced tensions which seemed to arise between my non-Indo-Canadian colleagues and their students. After all, they did not understand why their students often sought out the peach-coloured crayon to shade in their self-portraits. My fellow teachers did not understand why some parents did not wish for their daughters to play with boys during gym and recess. Nor could they understand why many of the students referred to adults (sometimes strangers) as "aunties" and "uncles." I felt I understood where these children were coming from-that I got them and that this inside knowledge I possessed situated me in a better place than my colleagues in our work as teachers. It was only later, upon re-entering the university landscape as a graduate student, that I was awakened (Greene, 1995) to how storying my students, my colleagues, and my peers along such unyielding plotlines was simply another iteration of picking up the peach-coloured crayon. In effect, I was colouring over the diverse stories of the very people I hoped to come alongside in my teaching.

As a doctoral student I am learning to inquire narratively into my stories to live by. These are stories which Clandinin et al. (2006) suggest, "are multiple, fluid, and shifting, continuously composed and recomposed in the moment to moment living alongside children, families, administrators and others both on and off the school landscape" (p. 9). Holding the mirror up to my stories to live by had shattered the story I held of myself as a culturally sensitive teacher. Heilbrun (1988) helps me to recollect, "We tell ourselves stories of our past, make fictions or stories of it, and these narrations become the past" (p. 51[original emphasis]). Coming face to face with myself, new knowings emerged from amongst the fragmented pieces of my old knowings (Anzaldua, 1987/1999) and I wondered, like Paley (1979/2000) before me, "How much does it matter if a child cannot identify ethnically or racially with a teacher? Does it matter at all?" (p. 35). Certainly, in facing myself (Anzaldua, 1987/1999; Lindemann Nelson, 1995), I saw that I had been writing over the familial stories of the young girl in my class and had not bothered to cast a focused eye upon the stories I silenced. In his conversations with me, I soon 
learned that despite some shared cultural background, my student's father did not see me as an appropriate role model for his daughter. What he viewed as negative traits in his daughter I saw as positive ones. His story of his daughter bumped up against the one I had of her which honoured her as an intelligent, articulate, and creative student. Her parents and, in particular, her father, had created a plotline of their daughter which framed her as the disobedient daughter.

Slipping in and out of time, inquiring into my stories of school and family affords me a liminal space (Heilbrun, 1999) to dwell whereby I can continue to shape and re-shape my understandings of what it will mean to ethically inquire into the experiences of my future participants. I am drawn closer to narrative inquiry with its dual ontological and methodological commitments to the relational (Caine, Estefan, \& Clandinin, 2013), as being a site for memory, imagination (Greene, 19956; Sarbin, 20047), and possibility (Greene, 1995; Lindemann Nelson, 1995). As I move towards a forward-looking story of myself as a narrative inquirer, I know that while I must tread cautiously, I must also be willing "to break with the taken-for-granted" (Greene, 1993, p. 211).

\section{Resonances}

Several ideas seemed to resonate as we shared some of our experiences related to diversity, in the telling and retelling (Clandinin \& Connelly, 2000) of our stories. Anzaldua (1987/1999) uses the term la facultad to refer to an ability that is developed when habitual modes of seeing reality are broken and new ways of seeing are created. La facultad is "anything that breaks into one's everyday mode of perception, that causes a break in one's defenses and resistance, anything that takes one from one's habitual grounding, causes the depth to open up, causes a shift in perception" (p. 61). It is a way of experiencing the self. Inquiring into who we are and are becoming as researchers allows us to be present to the ways we frame our experiences within habitual modes of perception.

We are also drawn to Lindemann Nelson (1995) who speaks of facing oneself as a bridge to valuing difference. In facing ourselves, we occupied spaces of contradictions and tensions, spaces Heilbrun (1999) imagined as liminal. Liminality, for Heilbrun, is experience at the threshold:

The word 'limen' means 'threshold,' and to be in a state of liminality is to be poised upon uncertain ground, to be leaving one condition or country or self and entering 
upon another. But the most salient sign of liminality is its unsteadiness, its lack of clarity about exactly where one belongs and what one should be doing, or wants to be doing. (p. 3)

Dwelling within these spaces of liminality, we awakened to the different ways in which we had perhaps storied people and how they may have storied us. Adichie (2009) compels us to consider the dangers to be found in simply attending to single stories, noting, "It is impossible to engage properly with a place or a person without engaging with all of the stories of that place and that person." She stresses that the single story "robs people of dignity. It makes our recognition of our equal humanity difficult. It emphasizes how we are different rather than how we are similar."

\section{Moving Forward as Narrative Inquirers}

As we inquired into our stories, ever conscious of the fluidity of time, place, and relationships, we were mindful of always being in the midst of a multiplicity of storiesthe personal, social, institutional, cultural, linguistic, and familial stories that we all live by and within (Clandinin, 2013). As Muna told and retold her stories she began to understand how living behind what she began to see as a defensive wall could create "structured silences" in her relationships. As she awakened to retelling her stories, she came to see that such silences would not allow her to come alongside participants in the relational methodology of narrative inquiry. As Jean told and retold her stories, she began to allow for the possibility of meeting Truong in ways that allowed both of them to be more than single stories, caught within narrow and structured plotlines. It was only in creating a space between that allowed them both to become, that they could do the work of engaging in relational narrative inquiry. As Jinny told and retold her stories, she began to see that she needed to allow for the multiplicity of stories that we each live and tell, stories that we know are shaped by, and which shape, multiple cultural, social, institutional, and familial stories. Holding close this multiplicity of stories, she imagined narrative inquiry spaces as ways of being attentive to a diversity of lives.

In our "effort[s] to gain perspective on our constructs and our categories" (Greene, 1993, p. 211), in our efforts to face ourselves and break with the taken-for-granted, the ethical necessity of this challenging work was brought to the foreground. With the profound conviction that "there must be a confronting of the contradictions, the instances of savagery, the neglect, and the possibility of care" (p. 220) in our research relationships, we courted and embraced uncertainty, vulnerability, and tension in our 
autobiographical tellings and retellings. As we puzzled about how to come alongside diverse participants, what became clear is that, just as there can never be a single story of experience, there can never be a single story of how to open narrative inquiry spaces of belonging. Rather, "there can only be a conversation drawing in voices kept inaudible over the generations, a dialogue involving more and more living persons ... never reaching a final conclusion, always incomplete, but richer and more densely woven" (pp. 212-213) as we work to attend to and honour the complexity of lives lived in different places, in different times, and structured by different landscapes.

\section{Notes}

1. Drawing upon Dewey's (1938) conception of experience as the interplay between continuity and interaction enacted in situations, Clandinin and Connelly (2000) conceived of the three-dimensional narrative inquiry space as attending to the interactions of the dimensions of temporality (past, present, and future), sociality (the relationship between the personal and the social), and place (the context by which, or within which, lived experiences are shaped).

2. Research Issues is a weekly cross-cultural, intergenerational, and interdisciplinary gathering place at the University of Alberta for graduate students, teachers, faculty, and visitors to share and inquire into stories of experience.

3. "Stories to live" by is a term used to refer to a narrative conception of identity (Connelly \& Clandinin, 1999).

4. Lindemann Nelson (1995) differentiated between found communities, those of place, and chosen communities, those we voluntarily form and/or choose to join.

5. By bumping up, we draw attention to the tensions that live between an individual's stories to live by and the stories that others live and tell.

6. Imaginative capacity, observes Greene (1995), "is to see beyond what the imaginer has called normal or "common-sensible" and to carve out new orders in experience" (p. 19).

7. For Sarbin (2004), "The greater the degree of embodied involvement in narrativeinspired imaginings, the more likely that the reader or listener will "feel with" or identify with the protagonist's efforts to resolve the moral issues central to a particular plot" (p. 17). 


\section{References}

Adichie, C. (2009, July). The danger of a single story [video file]. Retrieved from: http://www. ted.com/talks/chimamanda_adichie_the_ danger_of_a_single_story.html

Anzaldua, G. (1987/1999). Borderlands/La frontera: The new mestiza. San Francisco: Aunt Lute.

Caine, V., Estefan. A., \& Clandinin, D. J. (2013). $A$ return to methodological commitment: Reflections on narrative inquiry. Scandinavian Journal of Educational Research, 57(6), 574-586. doi:10.1080/003138 31.2013.798833

Chung, S. (2008). Composing a curriculum of lives: A narrative inquiry into the interwoven intergenerational stories of teachers, children, and families. Unpublished masters thesis, University of Alberta, Edmonton, Alberta, Canada.

Clandinin, D. J. (2013). Engaging in narrative inquiry. Walnut Creek, CA: Left Coast Press.

Clandinin, D. J., \& Caine, V. (2012). Narrative inquiry. In A. A. Trainor \& E. Graue (Eds.), Reviewing qualitative research in the social sciences (pp. 166-179). New York: Routledge.

Clandinin, D. J., \& Connelly, F. M. (1995). Teachers' professional knowledge landscapes. New York: Teachers College Press.

Clandinin, D. J., \& Connelly, F. M. (2000). Narrative inquiry: Experience and story in qualitative research. San Francisco: Jossey-Bass Publishers.

Clandinin, D. J., Huber, J., Huber, M., Murphy, M. S., Murray Orr, A., Pearce, M. et al. (2006). Composing diverse identities: Narrative inquiries into the interwoven lives of children and teachers. London: Routledge.

Connelly, F. M., \& Clandinin, D. J. (1999). Shaping a professional identity: Stories of educational practice. New York: Teachers College Press.
Connelly, F. M., \& Clandinin, D. J. (2006). Narrative inquiry. In J. Green, S. Camilli, \& P. B. Elmore (Eds.), Handbook of complementary methods in education research (pp. 477-489). Washington, DC: American Educational Research Association.

Greene, M. (1993). Diversity and inclusion: Toward a curriculum for human beings. Teachers College Record, 95(2), 211-221.

Greene, M. (1995). Releasing the imagination: Essays on education, the arts, and social change. San Francisco: Jossey-Bass Publishers.

Heilbrun, C. (1988). Writing a women's life. New York: Norton.

Heilbrun, C. (1999). Women's lives: The view from the threshold. Toronto, ON: University of Toronto Press.

Houle, S. T. (2012). A narrative inquiry into the lived curriculum of Grade 1 children identified as struggling readers: Experiences of children, parents, and teachers. Unpublished doctoral dissertation, University of Alberta, Edmonton, Alberta, Canada.

Huber, J., Murphy, M. S., \& Clandinin, D. J. (2011). Places of curriculum making: Narrative inquiries into children's lives in motion. London: Emerald.

Huber, M., Clandinin, D. J., \& Huber, J. (2006). Relational responsibilities of narrative inquirers. Curriculum and Teaching Dialogue, 8(2), 209-223.

Lindemann Nelson, H. (1995). Resistance and insubordination. Hypatia, 10(2), 23-40.

Paley, V. (1995). Kwanzaa and me: A teacher's story. Cambridge, MA: Harvard University Press.

Paley, V. (1979/2000). White teacher. Cambridge, MA: Harvard University Press.

Sarbin, T. R. (2004). The role of imagination in narrative construction. In C. Daiute \& C. Lightfoot (Eds.), Narrative analysis: Studying the development of individuals in society. Thousand Oaks: Sage. 


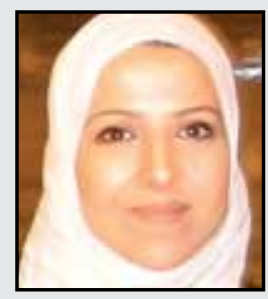

Muna Saleh is a PhD student in the Faculty of Elementary Education at the University of Alberta. She is also a member of the university's Centre for Research for Teacher Education and Development within the Faculty of Education. Muna draws upon her rich experience as a parent, student, teacher, administrator, and school board member in her doctoral work. She is looking forward to engaging in narrative inquiry alongside several Muslim students, families, and teachers in the near future.

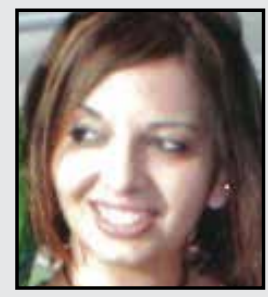

Jinny Menon is a doctoral student, currently enrolled in the Teacher Education Program in Elementary Education at the University of Alberta, where in 2012 she also obtained her Masters of Education in Educational Studies with a focus on school improvement and leadership. A former elementary school teacher and administrator, Jinny is interested in Narrative Inquiry as a relational methodology and looks forward to adopting a multiperspectival approach in her upcoming research.

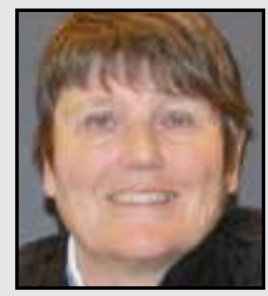

D. Jean Clandinin is Professor and Director, Centre for Research for Teacher Education and Development, University of Alberta. A former teacher, counselor, and psychologist, she and Michael Connelly co-authored four books including Narrative Inquiry (Jossey-Bass, 2000). Jean also authored Engaging in Narrative Inquiry (LeftCoast Press, 2013) and co-authored Composing Diverse Identities: Narrative Inquiries Into the Interwoven Lives of Children and Teachers (Routledge, 2006), Places of Curriculum Making: Children's Lives in Motion (Emerald, 2011) and Composing Lives in Transition: A Narrative Inquiry into the Lives of Early School Leavers (Emerald, 2013). She has won awards from AERA, University of Alberta, and Canadian Education Association. 